\title{
Social Security Contribution Rate and Its Impacts on Labor Demand of Enterprises in Carbon Neutral Context
}

\author{
Zhao Haizhu ${ }^{1}$, Luo Lianhua ${ }^{1 *}$ \\ ${ }^{1}$ School of Finance, Guangdong University of Finance \& Economics,510320, Guangzhou, China
}

\begin{abstract}
With the government setting stricter standard on carbon emission, enterprises are facing more environmental pressure and cost these years. At the same time, China's State Council has officially announced a further reducing the social security contribution rate from May 1, 2019, it is worthy of assessing that if the reduction would decompress enterprises and promote labor demand. Our results shows that social security contribution rate does not have significantly impacts on enterprises' labor demand overall. However, when wage and benefit are controlled, it has a direct impact on labor demand. Basic regression and heterogeneity analysis both confirm it. Wage and benefit play intermediary roles as the results show. Social security contribution rate has negatively impact on wage and benefit, which help to keep the total labor remuneration and then labor demand unchanged. State-owned and private enterprises show similar results. However, laborintensive and non-labor-intensive enterprises show slightly different results.
\end{abstract}

\section{Introduction}

Chinese statutory social security contribution rate of enterprises has been as high as about 30\% since the establishment of the social security system. Compared with the average level of OECD countries, China's social security contribution rate is far high, which has become a massive burden to enterprises, especially private ones $^{[1][2][3][4]}$ and leads to the contributions avoidance $^{[5][6][7]}$.

Global warming has become one of the top topics all over the world. Chinese government have paid much efforts to achieve carbon neutral and enterprises are confronted with more economic burden in the past decade. At the same time, economic growth is decreasing and social security contributions seem more cumbersome to enterprises, and they call for a reduction. The Government has taken some measures to lower down the corporate social security contribution rate. Existing literature suggest that when the costs of social security exceed the affordability of enterprises, the profits decrease ${ }^{[8][9]}$. And the enterprises will change their decisions on labor demand and further reduce costs by cutting the number of employees $^{[10][11]}$ (Beach \& Balfour, 1983; Lai \& Masters, 2005; Li \& Wu, 2011). However, what mechanisms will the social security contributions affect the labor demand has not been carefully examined. Our paper focuses on this topic and try to answer the question.

\section{Methodology}

\subsection{Data sources}

In our paper, the sample is limited to listed manufacturing enterprises in RESSET database in that manufacturing enterprises in China are labor-intensive and more sensitive to labor costs. China's listed companies have disclosed the data of social security fees according to the new Requirements of Accounting Standards in 2007. Hence, the sample years are 2007-2019. We exclude the ST, *ST samples, and the samples with less than 200 employees. And we conduct a two-sided tail reduction of $5 \%$ on all variables.

\subsection{Variables setting}

\subsubsection{Explained variable and explanatory variables}

The explained variable is the logarithm of employees' number. The RESSET database discloses the specific items of "payable salaries," including data about social security contributions and "wages, bonuses, and subsidies." We calculate the sum of "social security fees", "endowment insurance fees" and "unemployment insurance fees". " Health insurance fees", " maternity insurance fees" and "industrial injury insurance fees" are excluded for limited samples. We take the "salaries, bonuses, allowances and subsidies" as the "wages". And the social security contribution rate has the following two statistical definitions:

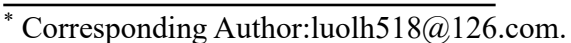




$$
\begin{aligned}
s s r 1 & =\frac{\text { increase of social security contributions for the year }}{\text { increase of wages, bonuses, allowances and subsidies for the year }} \\
s s r 2 & =\frac{\text { decrease of social security contributions for the year }}{\text { decrease of wages, bonuses, allowances and subsidies for the year }}
\end{aligned}
$$

\subsubsection{Intermediary variables}

We suppose that social security contributions will have impacts on labor demand by affecting wages, benefits, and total labor remuneration. We take per capita salary, per capita benefit, and per capita total labor remuneration as intermediary variables. The salary refers to "Wages, bonuses, allowances and subsidies", benefit refer to the difference between "payable salaries" and social security contributions and total labor remuneration refers to "cash paid to employees". All of them are divided by the number of employees and taken the logarithm of them.

\subsubsection{Control variables}

We control micro and macro variables. The micro variables are logarithm of asset size (size), asset-liability rate (dbastrt), return rate on Equity (roe), logarithm of income tax (tax), tangible assets ratio (fix) and two dummy variables of whether the enterprise is state-owned (gy) or private (my). The macro variables are logarithm of per capita GDP (pergdp), logarithm of per capita wage (pwage) and ratio of old-age population to working age population of the province where the enterprises are registered. And we also control the year dummy variables.

\section{Empirical analysis}

\subsection{Model construction}

We construct the basic fixed regression model as follows:

Table 1. Impacts of social security contribution rate on labor demand

\begin{tabular}{cccccc}
\hline & $\mathrm{m} 1$ & $\mathrm{~m} 2$ & $\mathrm{~m} 3$ & $\mathrm{~m} 4$ \\
\cline { 2 - 5 } & $\mathrm{ssr} 1$ & $-1.300^{* * *}$ & $0.179^{+}$ & 0.0323 & 0.0339 \\
& $(-15.70)$ & $(1.90)$ & $(0.46)$ & $(0.48)$ \\
Year & No & Yes & Yes & Yes \\
Micro & No & No & Yes & Yes \\
Variables & & & & \\
Macro & No & No & No & Yes \\
Variables & & & & $-4.414^{* * *}$ \\
cons & $7.587^{* * *}$ & $7.042^{* * *}$ & $-5.885^{* * *}$ & $(-3.30)$ \\
\hline$N$ & $(1198.03)$ & $(240.65)$ & $(-21.06)$ & 7180 \\
\hline
\end{tabular}

Note: $\mathrm{t}$ statistics in parentheses; $+\mathrm{p}<0.10,{ }^{*} \mathrm{p}<0.05,{ }^{* *} \mathrm{p}<0.01,{ }^{* * *} \mathrm{p}<0.001$.

\subsection{Intermediary effects of wage, benefit and labor remuneration} Table 2 shows the intermediary regression results of wage,
benefit and remuneration. The social security contribution Table 2 shows the intermediary regression results of wage,
benefit and remuneration. The social security contribution

$$
\text { lnworker }_{i t}=\alpha_{1}+\beta_{1} \text { ssr }_{i t}+\beta_{2} X_{i t}+\text { year }_{t}+\varepsilon_{i t}
$$

Where i represents the $\mathrm{i}$-th enterprise, and $\mathrm{t}$ is the $\mathrm{t}$-th year. $\alpha_{1}$ is the intercept. inworker ${ }_{i t}$ is the explained variable and $s s r_{i t}$ is the explanatory variable. $X_{i t}$ are the control variables. year $t_{t}$ is the dummy variable of years. $\beta_{1}$ and $\beta_{2}$ are the coefficients of explanatory variable and control variable. $\varepsilon_{i t}$ is the residual term.

To further investigate the intermediary effect, we also construct the following regression model:

$$
\begin{gathered}
\text { lnwage }_{i t}=\alpha_{2}+\beta_{3} \text { ssr }_{i t}+\beta_{4} X_{i t}+\text { year }_{t}+\mu_{i t} \\
\text { lnbenefit }_{i t}=\alpha_{3}+\beta_{5} \text { ssr }_{i t}+\beta_{6} X_{i t}+\text { year }_{t}+\vartheta_{i t} \\
\text { lntore }_{i t}=\alpha_{4}+\beta_{7} \text { ssr }_{i t}+\beta_{8} X_{i t}+\text { year }_{t}+\sigma_{i t}
\end{gathered}
$$

lnwage $_{i t}$, lnbenefit ${ }_{i t}$ and lntore $_{i t}$ are the intermediary variables. $\beta_{3}, \beta_{5}$ and $\beta_{7}$ are the coefficients that we're concerned in the intermediary regression models.

\subsection{Effects of social security contributions on labor demand}

Table 1 shows the impacts of social security contribution rate on employment. In $\mathrm{m} 1$, social security contribution rate has negative impacts on labor demand with no other variables controlled. In $\mathrm{m} 2$, the impacts is positive when years are controlled. In $\mathrm{m} 3$ and $\mathrm{m} 4$, the impacts are no longer significant with only micro variables controlled and both micro and macro variables controlled. Hence, the conclusions from the models are inconsistent. We may conclude that social security contribution rate does not have direct impacts on labor demand and the indirect impacts need to be further studied. rate has negative impacts on wage and benefit with $1 \%$ and $0.1 \%$ significant level, respectively. However, its impact on total labor remuneration is not significant, which means that the cost of social security contribution does not increase the total labor cost of the enterprises for they cut down the wage and benefit instead. And when 
there is no increase in labor cost, the labor demand won't decrease.

The last column of Table 2 shows the impacts of wage and benefit on labor demand are significantly negative, which confirm wage and benefit play intermediary role. When wage and benefit are controlled, the impact of social security contribution rate on labor demand is significantly negative, indicating that social security contribution rate has direct negative impacts on labor demand but wage and benefit cut help to keep the labor demand unchanged.

Table 2. Impacts of social security contribution rate on wage, benefit, labor remuneration and labor demand

\begin{tabular}{ccccc}
\hline & wage & benefit & tore & employee \\
\hline ssr1 & $-0.168^{* *}$ & $-3.396^{* * *}$ & 0.0589 & $-0.629^{* * *}$ \\
& $(-3.03)$ & $(-42.18)$ & $(1.10)$ & $(-8.84)$ \\
wage & & & & $-0.477^{* * *}$ \\
& & & & $(-29.46)$ \\
benefit & & & & $-0.172^{* * *}$ \\
& & & & $(-15.35)$ \\
Control Variables & Yes & Yes & Yes & Yes \\
cons & $4.708^{* * *}$ & 2.470 & $4.950^{* * *}$ & -1.748 \\
& $(4.46)$ & $(1.62)$ & $(4.86)$ & $(-1.51)$ \\
\hline$N$ & 7180 & 7167 & 7180 & 7167 \\
\hline
\end{tabular}

Note: $\mathrm{t}$ statistics in parentheses; $+\mathrm{p}<0.10,{ }^{*} \mathrm{p}<0.05,{ }^{* *} \mathrm{p}<0.01,{ }^{* * *} \mathrm{p}<0.001$.

\subsection{Heterogeneity analysis}

Table 3 shows the fixed regression results of state-owned and private enterprises. The social security contribution rate has significantly negative impacts on wage and benefit but has no significant impacts on total labor remuneration, both in state-owned and private enterprises. And the wage and benefit have negative impacts on labor demand. Therefore, the intermediary effects of wage and benefit exist both in state-owned and private enterprises.

The social security contribution rate's impact on labor demand become significant only when wage and benefit controlled both in state-owned and private enterprises. However, the impact to private enterprises' labor demand (the coefficient is -0.963) is stronger than to the stateowned enterprises' (the coefficient is -0.620). Private enterprises could be more 'afraid' of social security cost.

Table 3. Impacts of social security contributions on the labor demand of state-owned and private enterprises

\begin{tabular}{|c|c|c|c|c|c|c|c|c|c|c|}
\hline & \multicolumn{5}{|c|}{ State-Owned } & \multicolumn{5}{|c|}{ Private } \\
\hline & wage & benefit & tore & employee & employee & wage & benefit & tore & employee & employee \\
\hline \multirow[t]{3}{*}{ ssr1 } & - & - & - & 0.0662 & $-0.620^{* * *}$ & $-0.160^{+}$ & - & 0.129 & -0.0749 & $-0.963^{* * *}$ \\
\hline & $0.232^{* *}$ & $3.249^{* * *}$ & 0.0141 & & & & $3.829^{* * *}$ & & & \\
\hline & $(-2.86)$ & $(-27.01)$ & $(-0.19)$ & $(0.66)$ & $(-6.29)$ & $(-1.87)$ & $(-32.16)$ & $(1.52)$ & $(-0.68)$ & $(-8.47)$ \\
\hline \multirow[t]{2}{*}{ wage } & & & & & $-0.553^{* * *}$ & & & & & $-0.403^{* * *}$ \\
\hline & & & & & $(-22.34)$ & & & & & $(-17.74)$ \\
\hline \multirow[t]{2}{*}{ benefit } & & & & & $-0.172^{* * *}$ & & & & & $-0.215^{* * *}$ \\
\hline & & & & & $(-10.28)$ & & & & & $(-13.20)$ \\
\hline \multirow{4}{*}{$\begin{array}{l}\text { Control } \\
\text { Variables } \\
\text { _cons }\end{array}$} & Yes & Yes & Yes & Yes & Yes & Yes & Yes & Yes & Yes & Yes \\
\hline & & & & & & & & & & \\
\hline & 5.090 & 1.289 & 5.601 & -5.027 & -1.983 & $5 . / 71$ & 3.447 & 6.220 & -5.783 & -2.714 \\
\hline & (2.74) & $(0.47)$ & $(3.26)$ & $(-2.17)$ & $(-1.03)$ & $(4.20)$ & (1.80) & $(4.54)$ & $(-3.28)$ & $(-1.75)$ \\
\hline$N$ & 2466 & 2454 & 2466 & 2466 & 2454 & 4080 & 4080 & 4080 & 4080 & 4080 \\
\hline
\end{tabular}

We define operating income divided by employee as an indicator of labor-intensive. If an enterprise's labor intensive is higher than the median, we take it as a laborintensive enterprise. Otherwise, we take it as a non-labor -intensive enterprise. Table 4 shows the fixed regression results of labor-intensive and non-labor-intensive enterprises. For the labor-intensive enterprises, social security contribution rate has significantly negative impacts on wage and benefit but no significant impact on total labor remuneration in labor-intensive enterprises. When wage and benefit are not controlled, it can promote labor demand with 5\% significant level. However, the coefficient become negative when wage and benefit are controlled. We may conclude that although laborintensive enterprises are 'afraid' of social security cost, they can cut more wage and benefit to handle it for rely on low-skilled employees, who expect to be covered by social security system regardless of the huge cut of wage 
and benefit. Thus, social security contributions help them to attract the low-skilled employees.

For the non-labor-intensive enterprises, social security contribution rate has only negative impact on benefit but no impacts on wage and benefit. And the impact on labor demand become significant only when wage and benefit are controlled. It means that non-labor-intensive enterprises rely on high-skilled employees and it is not a smart choice to cut wage to handle the social security cost. The reduced benefit helps them to keep labor demand unchanged even though social security contribution rate has direct negative impact on labor demand.

Table 4. Impacts of social security contributions on labor-intensive and non-labor-intensive enterprises

\begin{tabular}{|c|c|c|c|c|c|c|c|c|c|c|}
\hline & \multicolumn{5}{|c|}{ Labor-Intensive } & \multicolumn{5}{|c|}{ Non-Labor-Intensive } \\
\hline & wage & benefit & tore & employee & employee & wage & benefit & tore & employee & employee \\
\hline ssr1 & $-0.148^{*}$ & $\begin{array}{c}- \\
3.719^{* * *}\end{array}$ & 0.0220 & $0.188^{*}$ & $-0.332^{* * *}$ & -0.138 & $3.115^{* * *}$ & 0.119 & -0.105 & $-0.598^{* * *}$ \\
\hline & $(-2.48)$ & $(-38.36)$ & $(0.37)$ & $(2.35)$ & $(-3.55)$ & $\begin{array}{c}(- \\
1.63)\end{array}$ & $(-25.69)$ & $(1.53)$ & $(-1.08)$ & $(-6.18)$ \\
\hline wage & & & & & $\begin{array}{c}-0.392^{* * *} \\
(-15.33)\end{array}$ & & & & & $\begin{array}{c}-0.431^{* * *} \\
(-20.09)\end{array}$ \\
\hline benefit & & & & & $\begin{array}{c}-0.124^{* * *} \\
(-7.93)\end{array}$ & & & & & $\begin{array}{c}-0.139^{* * *} \\
(-9.29)\end{array}$ \\
\hline $\begin{array}{c}\text { Control } \\
\text { Variables }\end{array}$ & Yes & Yes & Yes & Yes & Yes & Yes & Yes & Yes & Yes & Yes \\
\hline _cons & $\begin{array}{c}7.698^{* * *} \\
(6.42) \\
\end{array}$ & $\begin{array}{l}3.431^{+} \\
(1.75) \\
\end{array}$ & $\begin{array}{c}8.270^{* * *} \\
(6.90) \\
\end{array}$ & $\begin{array}{c}-4.224^{* *} \\
(-2.62)\end{array}$ & $\begin{array}{l}-0.781 \\
(-0.52) \\
\end{array}$ & $\begin{array}{l}3.785^{*} \\
(2.33) \\
\end{array}$ & $\begin{array}{l}4.982^{*} \\
(2.13) \\
\end{array}$ & $\begin{array}{l}3.770^{*} \\
(2.52)\end{array}$ & $\begin{array}{c}-6.471^{* * *} \\
(-3.46)\end{array}$ & $\begin{array}{l}-4.175^{*} \\
(-2.53) \\
\end{array}$ \\
\hline$N$ & 3568 & 3568 & 3568 & 3568 & 3568 & 3612 & 3599 & 3612 & 3612 & 3599 \\
\hline
\end{tabular}

Note: t statistics in parentheses; ${ }^{+} \mathrm{p}<0.10,{ }^{*} \mathrm{p}<0.05,{ }^{* *} \mathrm{p}<0.01,{ }^{* * *} \mathrm{p}<0.001$

\section{Conclusion and policy implications}

Our paper found that:(1) Social security contribution rate does not have significantly impacts on labor demand overall. But when wage and benefit are controlled, it has a direct impact on labor demand. Basic regression and heterogeneity analysis both confirms that. (2) Wage and benefit play intermediary roles as the results show. Social security contribution rate has negatively impacts on wage and benefit, which help to keep the total labor remuneration and then labor demand unchanged. (3) For labor-intensive enterprises, the social security contribution rate can promote the labor demand for it help enterprises attract low-skilled employees, even though the wage and benefit would be cut down by a large part. (4) For non-labor-intensive enterprises, the benefit but not the wage plays an intermediary role in the regression for highskilled employees' wage cut would result in talent loss.

The Chinese government has announced higher taxes and fees reduction policies. Our conclusions help analyze the impacts of such policies on labor demand, wages, benefits, and total labor remuneration. The reduction policy may not improve labor demand, but can improve employees' wage and benefit.

\section{Acknowledgement}

The project of Guangdong Natural Science Foundation" Labor Market Effect and the Optimal Rate Estimate of Social Security Contributions under the Supply-side Reform" (project number: 2018 A0303100014) support our research.

\section{References}

1. Z.W Wang, D.S Deng, Fund Gap, Contributions Ratio, and Financial Affordability: A study on Contribution Capacity of Social Security Subjects.C.S.S10,73-81(2009).

2. F.H Xu et al. Aging Population, Social Security Contributions, and Birth of Enterprises. E.T.T.E.M 11,54-63(2015).

3. Z.T Xu, S.Q Ding. Comparative Study on the Payment Capacity of Social Security of Enterprises with Different Ownership Systems in Different Regions. I.R 4,102-109(2014).

4. J.K Tao et al. "Crowding-out Effect" of Social Security Contributions on Labor Demand. C.P 6,7887(2016).

5. R.Q Wang et al. Is the Social Security Burden in China High or Low?- An Empirical Analysis of Actual Payment by Enterprises and Employees. J.J.U.F.E 6,53-63(2017).

6. B.W Zheng. Estimation of "Loss" of Social Security and Deep Analysis of Causes - From the levy of tax authorities. Pension Finance Review (series 7, 2019). China Pension Finance Forum of 50 Individuals, 20(2019).

7. J. Zhao et al. Social Security Contribution Rate, Participation Probability, and Payment Level - An empirical study on employees' and enterprises' behaviors of avoiding fees. E 1,341-372(2015).

8. S. Emmanuel et al.. Earnings Determination and Taxes: Evidence from a Cohort-Based Payroll Tax Reform in Greece. Q.J.E 127,493-533(2012).

9. Z.G Li, M.Q. Wu. Estimating the Incidences of the 
Recent Pension Reform in China: Evidence from 100,000 Manufacturers. C.E.P 31,32-44(2013).

10. C. Beach, F.S Balfour. Estimated Payroll Tax Incidence and Aggregate Demand for Labor in the United Kingdom. E 50,35-48(1983).

11. Y.C Lai, M. Stanley. The Effects of Mandatory Maternity and Pregnancy Benefits on Women's Wages and Employment in Taiwan,1984-1996. I.R 58,274-281(2005). 